
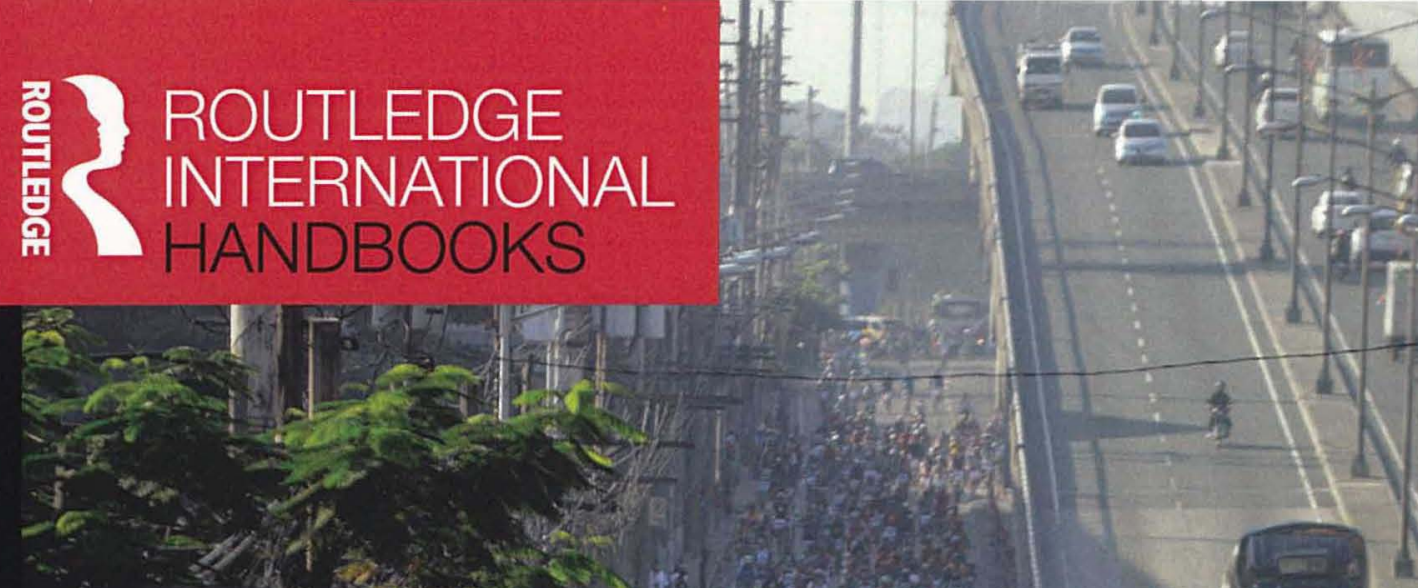


\section{Routledge International Handbook of Social and Environmental Change}

Edited by Stewart Lockie, David A. Sonnenfeld and Dana R. Fisher 
First published 2014

by Routledge

2 Park Square, Milton Park, Abingdon, Oxon OX14 4RN

and by Routledge

711 Third Avenue, New York, NY 10017

Routledge is an imprint of the Taylor \& Francis Group, an inforna business

(C) 2014 selection and editorial material Stewart Lockie, David A.

Sonnenfeld and Dana R. Fisher; individual chapters, the contributors

The right of the editors to be identified as the authors of the editorial material, and of the authors for their individual chapters, has been asserted in accordance with sections 77 and 78 of the Copyright, Designs and Patents Act 1988.

All rights reserved. No part of this book may be reprinted or reproduced or utilized in any form or by any electronic, mechanical, or other means, now known or hereafter invented, including photocopying and recording, or in any information storage or retrieval system, without permission in writing from the publishers.

Trademark notice: Product or corporate names may be trademarks or registered trademarks, and are used only for identification and explanation without intent to infringe.

British Library Cataloguing-Publication Data A catalogue record for this book is available from the British Library

Library of Congress Cataloging in Publication Data

Routledge international handbook of social and environmental change / edited by Stewart Lockie, David A. Sonnenfeld and Dana R. Fisher. pages $\mathrm{cm}$

Includes bibliographical references and index.

ISBN 978-0-415-78279-1 (hardback) - ISBN 978-0-203-81455-0

(ebook) 1. Social change-Environmental aspects. 2. Social change.

3. Global environmental change-Social aspects. 4. Climate change.

I. Lockie, Stewart. II. Sonnenfeld, David Allan. III. Fisher, Dana,

1971-HM856.R68 2013

303.4- dc23

2013011534

ISBN: 978-0-415-78279-1 (hbk)

ISBN: 978-0-203-81455-0 (ebk)

Typeset in Bembo

by Cenveo Publisher Services

Printed and bound in the United States of America by Publishers Graphics, LLC on sustainably sourced paper. 


\section{Contents}

List of illustrations

viii

Notes on contributors $\quad i x$

Acknowledgements $x v$

1 Socio-ecological transformations and the social sciences 1

Stewart Lockie, David A. Sonnenfeld and Dana R. Fisher

\section{PART I}

\section{Challenges, contradictions and consequences of global} socio-ecological change

2 Ecological modernization theory: taking stock, moving forward

Arthur P.J. Mol, Gert Spaargaren and David A. Sonnenfeld

3 The emergence of new world-systems perspectives on global environmental change

Andrew K. Jorgenson and Jennifer E. Givens

4 China's economic growth and environmental protection: approaching a 'win-win' situation? A discussion of ecological modernization theory

Dayong Hong, Chenyang Xiao and Stewart Lockie

5 Eco-imperialism and environmental justice

Anja Nygren

6 Neoliberalism by design: changing modalities of market-based environmental governance

Stewart Lockie

7 Dilemmas for standardizers of sustainable consumption 
PART II

Climate change, energy and adaptation

8 Climate, scenario-building and governance: comprehending the temporalities of social-ecological change

Stewart Lockie

9 From Rio to Copenhagen: multilateral agreements, disagreements and situated actions

Chukunmerije Okereke and Sally Tyldesley

10 Marriage on the rocks: sociology's counsel for our struggling energy-society relationships

Debra J. Davidson

11 Sustainability as social practice: new perspectives on the theory and policies of reducing energy consumption Harold Wilhite

12 Environmental migration: nature, society and population movement Anthony Oliver-Smith

\section{PART III}

Urban environmental change, governance and adaptation

13 Climate change and urban governance: a new politics?

Harriet Bulkeley

14 Recovering the city level in the global environmental struggle: going beyond carbon trading

Saskia Sassen

15 Hybrid arrangements within the environmental state

Dana R. Fisher and Erika S. Svendsen

16 The new mobilities paradigm and sustainable transport: finding synergies and creating new methods

Rachel Aldred

\section{PART IV}

17 Towards a socio-ecological foundation for environmental risk research 
18 Uncertainty and claims of uncertainty as impediments to risk management

Raymond Murphy

19 Transboundary risk governance: co-constructing environmental issues and political solutions

Rolf Lidskog

20 The role of professionals in managing technological hazards: the Montara blowout

Jan Hayes

21 Social learning to cope with global environmental change and unsustainability

J. David Tabara

\section{PART V}

(Re)assembling social-ecological systems

22 The social-ecological co-constitution of nature through ecological restoration: experimentally coping with inevitable ignorance and surprise

Matthias Gross

23 Biological invasions as cause and consequence of 'our' changing world: social and environmental paradoxes

Cécilia Claeys

24 Biological resources, knowledge and property

Luigi Pellizzoni

25 Disassembling and reassembling socionatural networks: integrated natural resource management in the Great Bear Rainforest

Justin Page

26 Land use tensions for the development of renewable sources of energy Gioryio Osti

Index 


\section{Illustrations}

\section{Tables}

6.1 Typology of market-based instruments 75

12.1 Estimates of people displaced by the effects of environmental change 148

13.1 The ICLEI Cities for Climate Protection milestone methodology 159

15.1 Distribution of hybrid arrangements 183

16.1 Contrasting approaches to transport planning 197

20.1 Summary of well control barriers $\quad 245$

21.1 Interpretations of environmental impairment 261

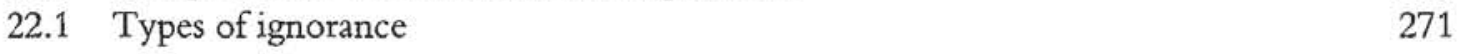

\section{Figure}

26.1 Framework of renewable energy source development in rural areas 


\section{Contributors}

Rachel Aldred is a sociologist based in the Westminster University Department of Planning and Transport. She has written extensively on cycling, having led the ESRC Cycling Cultures research project (2010-11). Current projects include the ESRC seminar series, Modelling on the Move, and the ESRC Secondary Data Analysis project, Changing Commutes.

Magnus Boström is Associate Professor in Sociology and environmental lecturer at Södertörn University, Sweden. His research and teaching interest generally concern politics, governance, participation, communication, organization and responsibility in relation to transnational environmental issues. He has studied how political, regulatory, organizational and discursive circumstances shape green consumerism and organized activism. His recent publications include the books Eco-standards, Product Labelling and Green Consumerism (Palgrave, 2008), co-authored with Mikael Klintman, and Transnational Multi-Stakeholder Standardization: Organizing Fragile NonState Authority (Edward Elgar, 2010), co-authored with Kristina Tamm Hallström. He has also written several articles on these topics.

Harriet Bulkeley is Professor at the Department of Geography, Durham University. Her research interests are in the nature and politics of environmental governance and focus on climate change, energy and urban sustainability. Her recent books include Cities and Climate Change: Critical Introductions to Urbanism and the City (Routledge, 2013), Governing Climate Change (with Peter Newell, Routledge, 2010), and Cities and Low Carbon Transitions (with Vanesa Castan-Broto, Mike Hodson and Simon Marvin, eds, Routledge, 2011).

Cécilia Claeys, Associate Professor at Aix-Marseille University, is a member of the LPED (Laboratoire Population Environnement Développement). An environmental sociologist, her research explores public policies, public perceptions and socio-technical controversies in the context of several topics including protected natural area creation, use and management, urban and suburban nature, invasive species management, and so on. Dr Claeys has developed interdisciplinary programmes drawing together the social and natural sciences, realising original field studies, exploring the epistemological heritages of the disciplines and developing theoretical debates between anthropocentrism and biocentrism.

Debra J. Davidson is Associate Professor of Environmental Sociology in the Department of Resource Economics and Environmental Sociology at the University of Alberta, with teaching and research interests in the social dimensions of energy and climate change. She is co-author of Challenging Legitimacy at the Precipice of Energy Calamity (2011, Springer), and recent articles have appeared in Science, British Journal of Sociology and Society and Natural Resources. She is currently a 
lead author of Chapter 26 of the Intergovernmental Panel on Climate Change's Fifth Assessment Report, Working Group II.

Dana R. Fisher is Associate Professor of Sociology and Director of the Program for Society and the Environment at the University of Maryland. Her research focuses on environmental policy, civic participation and activism more broadly. She has written extensively on climate politics in the USA and comparatively across nations, including National Governance and the Global Climate Change Regime (Rowman and Littlefield, 2004). Fisher is currently finishing up two grants from the US National Science Foundation: Comparing Climate Change Policy Networks (COMPON) project (co-investigator) and Understanding the Dynamic Connections Among Stewardship, Land Cover, and Ecosystem Services in New York City's Urban Forest (lead investigator). With support from the US Forest Service, she is expanding her work on urban stewardship to compare New York City to other cities, including Philadelphia.

Jennifer E. Givens is a Ph.D. student in Sociology at the University of Utah. Her interests include environmental sociology, global inequality and international development. Her published work appears in such venues as Social Science Research, Organization and Environment, Environment and Behavior and Nature and Culture.

Matthias Gross is Professor of Environmental Sociology at Helmholtz Centre for Environmental Research-UFZ in Leipzig and, by joint appointment, at the University of Jena, Germany. His current research focuses on the sociology of non-knowledge, experimental implementation strategies and the sociology of tapping geothermal energy. Co-founder and editor of the journal Nature and Culture, his most recent monograph is Ignorance and Surprise: Science, Society, and Ecological Design (MIT Press, 2010).

Jan Hayes has thirty years' experience in safety and risk management. Her current activities cover academia, consulting and regulation. She holds a Senior Research Fellow appointment at the Australian National University, where she is Program Leader for the social science research activities of the Energy Pipelines Co-operative Research Centre. Her research interests include decision making, safety in design, professionalism and learning. In addition, she consults part time with a small group of clients on safety performance improvement projects. Dr Hayes is a member of the Advisory Board of Australia's National Offshore Petroleum Safety and Environmental Management Authority.

Dayong Hong is Professor of Sociology at Renmin University of China, the Director of the Institute of Environmental Sociology, RUC, and also Chair of the Environmental Sociology Committee of the Chinese Sociological Association. His research focuses on the sociology of development, environmental sociology and social policy. His recent scholarly publications include Social Change and Environmental Problems (2001, Capital Normal University Press), Social Assistance in Transitional China (2004, Liaoning Education Press), The Growing Non-Govemmental Forces for Environmental Protection in China (with Chuanjin Tao Mei; 2007, Shizheng Feng), and The Social Bases of an Environmentally Friendly Society (with Chengyang Xiao, 2012; Renmin University of China Press).

Andrew K. Jorgenson is Professor and Director of Graduate Studies in Sociology at the University of Utah. The primary area of his research is coupled human and natural systems, with a focus on the political economy and human ecology of global environmental change. His secondary areas of research include the macro-level causes of public health outcomes in developing nations, the 
globalization of environmental concern and the political economy of development. His recent work appears in such venues as American Journal of Sociology, Social Problems, Social Forces, Social Science Research, Global Environmental Politics, Ecological Economics, Urban Studies and PLoS ONE.

Mikael Klintman is Professor of Sociology at Lund University, Sweden. His research addresses environmental and urban issues, science and technology studies, public understandings of science, ethical and political consumption, social movements and globalization, policy analysis, and democracy and participation. Recent books include Citizen-Consumers and Evolutionary Theory: Reducing Environmental Harm Through our Social Motivation (Palgrave, 2012) and Eco-Standards, Product Labelling and Green Consumerism (with Magnus Böstrum, Palgrave, 2008).

Rolf Lidskog is Professor of Sociology at the Center for Urban and Regional Studies, Örebro University, Sweden. His research interests include environmental policy and politics at the international and national levels, especially the role of expertise in environmental governance. He has studied a variety of environmental policy areas: air pollution, climate change, biodiversity, nuclear waste and hazardous waste. He is co-author (with Linda Soneryd and Ylva Uggla) of the book Transboundary Risk Governance (Earthscan, 2009) and co-editor of Goveming the Air: The Dynamics of Science, Policy, and Citizen Interaction (MIT Press, 2011).

Stewart Lockie is Professor of Sociology and Director of The Cairns Institute at James Cook University, Australia. He is also President of the International Sociological Association's Research Committee on Environment and Society, a member of the International Council for Science's Committee on Scientific Planning and Review and a Fellow of the Academy of Social Sciences in Australia. Professor Lockie is an environmental sociologist with research interests in food production and consumption networks, environmental governance, natural resource management and risk governance. Recent publications include Risk and Social Theory in Environmental Management (co-edited with Thomas Measham; CSIRO Publishing, 2012) and Agriculture, Biodiversity and Markets: Livelihoods and Agroecology in Comparative Perspective (co-edited with David Carpenter; Earthscan, 2010).

Arthur P.J. Mol is Professor in Environmental Policy at both Wageningen University, the Netherlands, and Renmin University of China. He is also Director of the Wageningen School of Social Sciences, and co-editor of the journal Environmental Politics. His main fields of interests and publications are in globalization, social theory and the environment, information and transparency, environmental governance, ecological modernization, and sustainable production and consumption. His latest books are Environmental Reform in the Information Age (2008, Cambridge University Press) and The Ecological Modernisation Reader (edited with David A. Sonnenfeld and Gert Spaargaren, 2009, Routledge).

Raymond Murphy is Emeritus Professor, and former Chair, of the Department of Sociology at the University of Ottawa, Canada. He is past-president of the Environment and Society Research Committee of the International Sociological Association. Professor Murphy is author of Sociological Theories of Education (McGraw-Hill Ryerson, 1979); Social Closure (Oxford University Press, 1988), which was translated into Japanese; Rationality and Nature (Westview, 1994), which was translated into Korean; Sociology and Nature (Westview, 1997), named by the journal Choice as one of the Outstanding Academic Books published in the United States in 1997; and Leadership in Disaster: Learning for a Future with Global Climate Change (McGill-Queen's University Press, 2009). 


\section{Contributors}

Anja Nygren is an Associate Professor of Development Studies and Adjunct Professor of Environmental Policy at the University of Helsinki, Finland. She has long-term research experience in Costa Rica, Nicaragua, Honduras and Mexico. Anja's research interests include environmental governance, political ecology, urban ethnography, risks and vulnerabilities, forests and society, certifications and fair trade, corporate responsibility, environmental justice and social movements. Anja is currently a leader of a research project, New Forms of Environmental Governance: Managing the Risks and Vulnerabilities in Southern Cities, funded by the Academy of Finland.

Chukwumerije Okereke is a Reader in Environment and Development at the School of Human and Environmental Sciences, University of Reading, UK. Before joining Reading, he was a Senior Research Fellow and Head, Climate and Development Centre at the Smith School of Enterprise and the Environment, University of Oxford. He remains a Visiting Fellow the Smith School and Oxford University's Environmental Change Institute (ECI). His research focuses on the links between global climate governance systems and international development.

Anthony Oliver-Smith is Professor Emeritus of Anthropology at the University of Florida. He has undertaken anthropological research on issues relating to disasters and involuntary resettlement in Peru, Honduras, India, Brazil, Jamaica, Mexico, Japan and the USA since the 1970s. His work on disasters has focused on issues of post-disaster social organization, including class/race/ ethnicity/gender based patterns of differential aid distribution, social consensus and conflict, grief and mourning issues and social mobilization of community-based reconstruction efforts. He has served on the Social Sciences Committee of the Earthquake Engineering Research Institute and is a member of La Red de Estudios Sociales en Prevención de Desastres en America Latina (The Network for Social Studies on Disaster Prevention in Latin America).

Giorgio Osti is a rural sociologist and Associate Professor in the Department of Political and Social Sciences, University of Trieste, Italy. He is interested in socio-spatial relationships and in the working of reciprocity in place. He has been involved in research concerning local development in fragile areas and environmental issues like waste management and energy transition. Recently he has published 'The moral basis of a forward society: Relations and forms of localism in Italy' (Local Economy, March 1, 2013).

Justin Page is an environmental sociologist with over ten years of experience examining the social dimensions of natural resource management. Dr Page has completed rigorous analyses of land use planning, conservation, public acceptability, community resilience, social capital, Aboriginal consultation, and environmental justice in the forestry, aquaculture, mining and fishing sectors. Currently an environmental consultant working on the social impacts of large-scale natural resource projects, Dr Page continues to contribute to our understanding of natural resource management policy, Aboriginal relations, and the social causes and consequences of environmental change.

Luigi Pellizzoni is Associate Professor in Environmental Sociology at the Department of Political and Social Sciences, University of Trieste. His research interests intersect two main areas: environment, technoscience and social change; and participation, conflict and transformation of the ways of governing. On these topics he has published some books and several articles (Global Environmental Change, Environmental Politics, European Journal of Social Theory, Theory Culture and

Society, etc.). In recent years he has especially focused on new mobilizations and the impact of new and emerging technosciences, with their regulatory arrangements, on the society-nature 
relationship. He is co-editor, with Marja Ylönen, of Neoliberalism and Technoscience: Critical Assessments (Ashgate, 2012).

Ortwin Renn is Professor and Chair of Environmental Sociology and Technology Assessment at Stuttgart University, Germany. He directs the Center for Interdisciplinary Risk and Innovation Studies at the University of Stuttgart (ZIRIUS) and the non-profit company DIALOGIK, a research institute for the investigation of communication and participation processes in environmental policy making. He also serves as Adjunct Professor for Integrated Risk Analysis at Stavanger University, Norway, and as Affiliate Professor at Beijing Normal University.

Saskia Sassen is the Robert S. Lynd Professor of Sociology and co-Chair of the Committee on Global Thought, Columbia University (www.saskiasassen.com). Recent books are Territory, Authority, Rights: From Medieval to Global Assemblages (Princeton University Press, 2008), A Sociology of Globalization (W.W. Norton, 2007), and the fourth edition of Cities in a World Economy (Sage, 2011). The Global City came out in a new edition in 2001. Her books are translated into over twenty languages. She is currently working on When Territory Exits Existing Frameworks (Harvard University Press). She contributes regularly to www.OpenDemocracy.net and www.HuffingtonPost.com.

David A. Sonnenfeld is Professor of Sociology and Environmental Policy at the State University of New York's College of Environmental Science and Forestry (SUNY ESF), in Syracuse, USA; and Research Associate, Environmental Policy Group, Wageningen University, the Netherlands. His research interests include environmental reform in newly industrializing countries, popular participation in environmental reform and technological environmental innovation. Among his most recent publications are Food, Globalization and Sustainability (with Peter Oosterveer, Earthscan, 2012) and The Ecological Modernisation Reader: Environmental Reform in Theory and Practice (co-edited with Arthur P.J. Mol and Gert Spaargaren, Routledge, 2009).

Gert Spaargaren is a Senior Researcher and Professor of Environmental Policy for Sustainable Lifestyles and Consumption at Wageningen University. His main research interests and publications are in the field of environmental sociology, sustainable consumption and behaviour and the globalization of environmental reform. His latest books are The Ecological Modernisation Reader (edited with Arthur P.J. Mol and David A. Sonnenfeld, Routledge, 2009) and Food in a Sustainable World; Transitions in the Consumption, Retail and Production of Food (edited with Peter Oosterveer and Anne Loeber, Routledge, 2011).

Erika S. Svendsen is a Research Social Scientist with the US Forest Service. Her work includes understanding the spatial, temporal and political aspects of environmental stewardship, focusing on governance and social well-being. Dr Svendsen is based in New York City, where she is the Forest Service representative to the NYC Urban Field Station. Founded in partnership with the New York City Department of Parks and Recreation, the Field Station's mission is to improve quality of life in urban areas by conducting and supporting research about social-ecological systems and natural resource management.

J. David Tàbara works at the Global Climate Forum and is Associate Senior Researcher at the Institute of Environmental Sciences and Technology at the Autonomous University of Barcelona. $\mathrm{He}$ is a member of the European Sustainability Science Group and a member of the Board of the 
Research Committee on Environment and Society of the International Sociological Association. Recently he has contributed to the following books: Making Climate Change Work for Us (Hulme et al., CUP, 2010), Reframing the Problem of Climate Change (Jaeger et al., Earthscan, 2011) and European Research for Sustainable Development. (Jaeger et al., Springer, 2011).

Sally Tyldesley is a Policy Adviser working within the Sustainability theme at the Royal Society's Science Policy Centre. Before joining the Royal Society, Sally was a research assistant at the Smith School of Enterprise and the Environment, University of Oxford. Her work focuses on climate science and policy, climate resilient development and energy.

Harold Wilhite is Professor of Social Anthropology and Research Director at the University of Oslo's Centre for Development and Environment. His main research interests have been associated with theorizing consumption in countries of both the North and South and developing innovative policy instruments promoting sustainable consumption. He has published widely on consumption, development and societal change based on ethnographic field studies in North America, Latin America, Japan, Norway and India. Over the past five years he has been Academic Director for the University of Oslo Interfaculty programme on sustainable energy and environmental change (MILEN).

Chenyang Xiao is Assistant Professor of Sociology at American University, USA. His research focuses on public beliefs of and attitudes towards environmental problems such as global warming, as well as general environmental values and worldviews, often with an international scope, and public attitudes towards science and technology. 


\section{Acknowledgements}

Undertaking a project such as this is not possible without the encouragement and support of numerous people, over a period of many months.

Gerhard Boomgaarden, Senior Publisher at Routledge, approached us with the idea for a compilation on the broad topic of environment and society, and was generous with his encouragement and advice as we refined and brought this idea to life. His colleague, Emily Briggs, Editorial Assistant at Routledge, has done a wonderful job of keeping us on track.

Contributors to the book have been uniformly easy to deal with. We thank them for their patience and responsiveness as we have worked through the processes of reviewing and editing their chapters.

We all were saddened by the passing in 2010 of William R. Freudenberg, Professor of Environmental Studies at the University of California, Santa Barbara. One of the intended contributors to this volume, Bill's work on the social causes of environmental degradation and disasters continue to be extremely influential, as is evident in its use by others whose work does appear here.

Lastly, we would like to thank all of our colleagues in the International Sociological Association's Research Committee on Environment Society (RC24), whose tireless and deeply thoughtful scholarship on societal and environmental change in many places around the globe deeply inspires us, giving us hope for a greener planet for generations to come. 